\title{
Metformin inhibits human T-cell leukemia virus type 1 transcription through activation of LKB1 and salt-inducible kinases
}

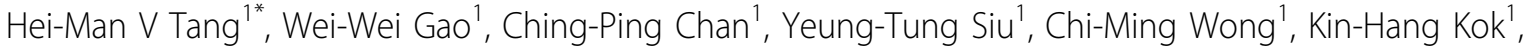 \\ Yick-Pang Ching ${ }^{2}$, Hiroshi Takemori ${ }^{3}$, Dong-Yan Jin ${ }^{1}$
}

From 16th International Conference on Human Retroviruses: HTLV and Related Viruses

Montreal, Canada. 26-30 June 2013

Human T-cell leukemia virus type 1 (HTLV-1) causes adult T-cell leukemia (ATL). Specific therapeutic and prophylactic agents are not available. Epidemiological studies have established a correlation between long-term use of the commonly prescribed anti-diabetic drug metformin and a decrease in the incidence of breast and other cancers. Whether metformin might also have antiHTLV-1 and anti-ATL activity is unclear. In this study we demonstrate an inhibitory effect of metformin on HTLV-1 transcription mediated through the activation of LKB1 tumor suppressor and downstream salt-inducible kinases (SIKs). Treatment of HTLV-1- transformed ATL cells or cells transfected with HTLV-1 molecular clone pX1MT with metformin led to reduction in cellfree virion production and inhibition of cell proliferation. This effect was attributed to the activation of LKB1/SIK1 which compromised Tax expression and HTLV-1 transcription. LKB1 and SIKs function as host restriction factors that counteract Tax activation of HTLV-1 long terminal repeats. Expression of LKB1 and activated SIKs effectively blunted Tax activity in a phosphorylation-dependent manner in LKB1-null HeLa cells, whereas compromising these kinases, but not AMPdependent protein kinases, augmented Tax function in LKB1-proficient HEK293T cells. Activated LKB1 and SIKs associated with Tax. Enforced expression of LKB1 or SIK1 in pX1MT-transfected cells and HTLV-1-transformed ATL cells repressed proviral transcription, whereas depletion of LKB1 boosted Tax expression. Taken together, our findings revealed a potential

\footnotetext{
* Correspondence: tanghmv@hku.hk

'Department of Biochemistry, The University of Hong Kong, Pokfulam, Hong Kong
}

Full list of author information is available at the end of the article therapeutic and prophylactic agent for ATL as well as a new negative regulatory function of LKB1 and SIKs in HTLV-1 transcription. (Supported by HKU7661/08M, HKU7674/12M, HKU1/CRF/11G and SKY-MRF-2011).

\section{Authors' details}

'Department of Biochemistry, The University of Hong Kong, Pokfulam, Hong Kong. ${ }^{2}$ Department of Anatomy, The University of Hong Kong, Pokfulam, Hong Kong. ${ }^{3}$ Laboratory of Cell Signaling and Metabolism, National Institute of Biomedical Innovation, Osaka, Japan.

Published: 7 January 2014

doi:10.1186/1742-4690-11-S1-P112

Cite this article as: Tang et al:: Metformin inhibits human T-cell leukemia virus type 1 transcription through activation of LKB1 and saltinducible kinases. Retrovirology 2014 11(Suppl 1):P112.

Submit your next manuscript to BioMed Central and take full advantage of:

- Convenient online submission

- Thorough peer review

- No space constraints or color figure charges

- Immediate publication on acceptance

- Inclusion in PubMed, CAS, Scopus and Google Scholar

- Research which is freely available for redistribution

Submit your manuscript at www.biomedcentral.com/submit
() Biomed Central 